\title{
Survey on Pesticide Use Pattern and Farmers Perceptions in Cauliflower and Brinjal Growing Areas in Three Districts of Himachal Pradesh, India
}

\author{
Gaganpreet Singh Brar*, Surender Kumar Patyal, \\ Jatiender Kumar Dubey and Gagandeep Singh
}

Department of Entomology, Dr YS Parmar University of Horticulture and Forestry, Nauni, Solan - 173 230, H.P., India

*Corresponding author

\begin{abstract}
A B S T R A C T
Pesticides have substantially contributed for controlling of pests and increasing crop yields. But over the years there is growing concern about indiscriminate use of pesticides

Keywords

CIBRC, Pesticide,

Malathion, Chlorpyrifos, Carbendazim, Insects

Article Info

Accepted:

20 February 2018

Available Online:

10 March 2018 in agriculture. A survey was conducted among 150 farmers in cauliflower and brinjal cultivating areas of Hamirpur, Bilaspur and Una districts Himachal Pradesh, India in 20152016. Most commonly used pesticides applied by the farmers on cauliflower and brinjal were malathion, chlorpyrifos, cypermethrin, carbendazim and mancozeb. It was also observed during the survey that most of the farmers stored the pesticide bottles $(81.33 \%)$ at safe places in their houses and the remaining (16.66\%) placed the bottles in unsafe areas without any safety measures. It was revealed that no farmer was familiar with Central Insecticides Board and Registration Committee (CIBRC) guidelines about the use of labelled and non-labelled pesticide application and majority of the farmers $(57.33 \%)$ were mainly dependent on the advice of pesticide dealers. CIBRC recommendations are yet to percolate down through various agencies to arrive at the farmers' level by educating them at various forums.
\end{abstract}

\section{Introduction}

Pest and disease infestations are common occurrences in agricultural production. Productivity of crops grown for human consumption is at risk due to the incidence of pests, especially weeds, pathogens and animal pests. Crop losses due to these harmful organisms can be substantial and may be prevented, or reduced, by crop protection measures (Oerket, 2005). Adequate knowledge on how farmers perceive pests, their attitude, and practices to crop protection problems are required to implement successful pest control programs (Ajayia, 2000). Horticulture is the main occupation of the people of Himachal Pradesh and has an important place in the economy of the state. It provides direct employment to about 70 per cent of the total workers of the state. Out of the total geographical area of 55.67 lakh hectares of the state, the area of operational holding is about 9.99 lakh hectares and is being operated by 8.63 lakh farmers (Anand 2015). Farmers of Hamirpur, Bilaspur and Una grow tomato, cabbage, capsicum, 
cauliflower, broccoli and other season crops as well as off season crops vegetables. These vegetable crops are attacked by various insect pests and diseases and cause reduction in yield.

In order to meet the growing demands of vegetables, fertilizers are used to increase productivity whiles pesticides are used to control pests. Pesticides, poisons chemical substances used in certain circumstances to kill specifically targeted pests (Wassemann, 1972). However, the recommended use of these pesticides vis-à-vis their effectiveness on wide range of pests; provoke the farmers to use them against pests of other crops also, on which they are not recommended to boost their economy. Though strict regulations have been laid down by international agencies like EPA and WHO (Nyakundi et al., 2010), in India agencies like Central Insecticide Board and Registration Committee (CIBRC) and Food Safety and Standard Authority of India (FSSAI) work regarding the pesticide manufacturing and usage however, the recommended dose, time and frequency of application of the pesticides are generally overlooked by the farmers (Gagan et al., 2016). At the same time not much attention is given to the requisite safety measures to be adopted and the recommended mode of application for different kinds of commonly used pesticides particularly in developing countries. In India Survey conducted by Gagan et al., (2016) in Solan, Shimla and Sirmour districts of Himachal Pradesh observed that farmers use pesticides to control pests which are not recommended by Central Insecticide Board and Registration Committee (CIBC) on vegetable crops. Chemical pesticides are the most effective, short-term control method for a variety of crop pests and pathogens but their ill effects on human, animal and environmental health have also been well established as they may enter into the environment through a variety of channels.
Some of these modes include percolation through soil particles and ground water, as a part of run-off water thus entering into surface water bodies, as aerosols when applied as sprays, as residues in various plant parts as well as soil and water organisms. Chemical pesticides tend to persist in soil, surface water bodies as well as ground water for long periods thus imposing serious health threat for humans and animals (Ongley, 1996). Apart from affecting the target pest, they also influence the native micro and maroflora of the agricultural soils and water (Lupwayi et al., 2009; Beketov et al., 2013). A number of ecological functions and properties are unfavorably influenced by chemical pesticides such as nutrient cycling, natural food webs and food chains, soil structure and fertility, soil and water biodiversity, natural balance between pest and predator insects and many others (Zacharia, 2011).

There are few studies related to these issues in India. Thus, studies focused on pesticide application practices and usage trends are highly required in order to understand farmer's perception. The present investigation was therefore undertaken to assess various aspects of pesticide usage patterns, farmer's views in pest knowledge and management in cauliflower and brinjal cultivating areas of districts Hamirpur, Bilaspur and Una, Himachal Pradesh, India.

\section{Materials and Methods}

A detailed random survey was carried out to gather information on various aspects of pesticide usage like knowledge of farmers about pest management, perceptions of the kind and frequency as well as severity of pests and diseases, sources of information, awareness of farmers, safety measures followed during pesticide application etc was collected. Out of 12 districts of the state of Himachal Pradesh, three districts namely 
Bilaspur, Hamirpur and Una were purposively selected for the study. The selection of the districts was influenced by two factors. First, these districts are the main brinjal crop producing districts of the state (Anonymous, 2015). Second, these three districts also cultivated good account of cauliflower crop. The information pertaining to knowledge and perception of pests and the pesticide use pattern by the growers in vegetable cultivation was collected from 150 farmers of the selected districts (50 farmers from each district). The respondents were not pre-informed so as to avoid biased responses and to gain actual insight of the farming practices. However, at the time of interview the farmers were apprised with the aim of the study. Interviews were conducted in local language and a verbal consent was taken from all the participants.

A clear cut understanding of farmers' knowledge, attitude and practices regarding labeled/non-labeled pesticide use as per the CIBRC approval and recommendation was the first step towards understanding the reasons for overuse/ misuse of pesticides by farmers. In order to have a better insight into farmers' pest management practices in crop production a detailed examination of farmers' pest control practices, intensity and composition of pesticides used, sources of information on the adoption of pesticide use and decision criteria on pesticide application at farm level was conducted. In addition to this, information regarding sources of information on pesticide use, toxicity levels, storage, disposal, application practices, sprayer maintenance, safety measures followed etc were also probed at farm level. An attempt to collect the data pertaining to the entry of pesticides in the state through various agencies involved in procurement such as government/private dealers/distributors was also made to draw the meaningful inference. Percentages and averages were computed and compared to draw meaningful inferences.

\section{Results and Discussion}

The results presented here are based on the voluntary participation of 150 randomly selected farmers of cauliflower and brinjal cultivating areas of districts Hamirpur, Bilaspur and Una, Himachal Pradesh, India. Among the 150 interviewed farmers, 14.25 per cent had received no formal education, 21.89 per cent were educated below secondary level, and 25.36 per cent farmers had finished schooling up to secondary level while a maximum of 30.85 per cent farmers had completed senior secondary schooling (Table 1). A small percentage of them i.e. 7.62 per cent have managed to achieve graduation degree. Majority of the interviewed farmers were varied between 21 years to 50 years of age. Only 11.48 per cent farmers were above the age of 50 year.

As was expected, all the farmers interviewed in this study reported to use various kinds of chemical pesticides. On the basis of information received during the survey it was concluded that three types of pesticides were prevalent in this area i.e. insecticides, fungicides and acaricides. Insecticides were found to be more popular than fungicides in both cauliflower and brinjal crops. A total of 10 pesticides were found as most widely used by the farmers (Table 2). Malathion (73.56 per cent) was discovered as the most popular and effective insecticide followed by chlorpyriphos (67.59 per cent) and cypermethrin (61.62 per cent) while among fungicides mancozeb (57.63 per cent) was found as the most commonly used and effective fungicide by the respondents followed by carbendazim (Table 2). Propargite (41.62 per cent) was found to be commonly used acaricide to control mite infestation in brinjal crop. Some systemic insecticides like imidacloprid, dimethoate and methyl demeton were also used to control sucking pests of cauliflower and brinjal. 
Table.1 General characteristics of the farmers growing cauliflower and brinjal

\begin{tabular}{|l|l|c|}
\hline S. No. & Particulars & Individuals (\%) \\
\hline $\mathbf{1}$ & Age & \\
\hline $20-30$ & 19.56 \\
\hline $30-40$ & 35.12 \\
\hline $40-50$ & 33.84 \\
\hline more than 50 & 11.48 \\
\hline Quilification & \\
\hline Illiterate & 14.25 \\
\hline Primary School & 21.89 \\
\hline Secondary School & 25.36 \\
\hline High School & 30.85 \\
\hline College & 7.62 \\
\hline
\end{tabular}

Table.2 Commonly used pesticides, their classification and usage in the site of study

\begin{tabular}{|r|l|l|l|l|r|}
$\begin{array}{r}\text { S. } \\
\text { No. }\end{array}$ & \multicolumn{1}{|c|}{$\begin{array}{c}\text { Type of } \\
\text { pesticide }\end{array}$} & \multicolumn{1}{|c|}{ Common name } & \multicolumn{1}{|c|}{$\begin{array}{c}\text { Trade name } \\
\text { class* }\end{array}$} & $\begin{array}{c}\text { \%age of } \\
\text { Farmers using }\end{array}$ \\
\hline $\mathbf{1}$ & Insecticide & Malathion & Cythion 50 EC & III & 73.56 \\
\hline $\mathbf{2}$ & Insecticide & Chlorpyriphos & Dursban, Durmet 20 EC & II & 67.59 \\
\hline $\mathbf{3}$ & Insecticide & Cypermethrin & Shakti 25 EC & II & 61.22 \\
\hline $\mathbf{4}$ & Fungicide & Mancozeb & Indofil M-45/Dithane M-45 & U & 57.63 \\
\hline $\mathbf{5}$ & Fungicide & Carbendazim & Bavistin 50 WP & U & 53.65 \\
\hline $\mathbf{6}$ & Insecticide & Profenofos & Profex 50 EC & II & 43.69 \\
\hline $\mathbf{7}$ & Acaricide & Propargite & Omite/Simba 57 EC & III & 41.62 \\
\hline $\mathbf{8}$ & Insecticide & Imidacloprid & Confidor 200 S.L & II & 31.00 \\
\hline $\mathbf{9}$ & Insecticide & Dimethoate & Tafgor 30 EC & II & 27.52 \\
\hline $\mathbf{1 0}$ & Insecticide & Methyl demeton & Metasystox 25 EC & Ib & 24.33 \\
\hline
\end{tabular}

$\mathrm{Ib}=$ Highly hazardous, $\mathrm{II}=$ Moderately hazardous, III= Slightly hazardous, U= Unlikely to cause acute hazard in normal use

Table.3 Farmers' knowledge about pest management practices

\begin{tabular}{l} 
Particulars \\
Have knowledge about pesticide hazards \\
\hline Have Heard about IPM practice \\
\hline Having knowledge about the pests
\end{tabular}

\begin{tabular}{|c|c|c|c|}
\hline Hamirpur & Bilaspur & Una & Average \\
\hline 67 & 63 & 57 & 62.33 \\
\hline 43 & 35 & 31 & 36.33 \\
\hline 59 & 51 & 47 & 52.33 \\
\hline
\end{tabular}

Table.4 Source of information for the adoption of pest management

\begin{tabular}{l} 
Sources of information \\
\hline Fellow farmer/ friends/ relatives \\
\hline SAU personnel / State Deptt. of Agric/ ICAR \\
Institute \\
\hline Pesticide dealers/ company representatives \\
\hline CIBRC guideline \\
\hline
\end{tabular}

\begin{tabular}{|r|r|r|r|} 
Hamirpur & Bilaspur & Una & Average \\
\hline 20 & 27 & 24 & 23.66 \\
\hline 25 & 14 & 19 & 19.33 \\
\hline 55 & 59 & 57 & 57.00 \\
\hline 0 & 0 & 0 & 0 \\
\hline
\end{tabular}


Table.5 Severity of pests in cauliflower and brinjal as perceived by the farmers

\begin{tabular}{|c|c|c|c|c|c|}
\hline \multirow[t]{2}{*}{ District } & \multirow[t]{2}{*}{ Crop } & \multirow[t]{2}{*}{ Pest } & \multicolumn{3}{|c|}{ Severity of insects and diseases } \\
\hline & & & Slight & Medium & Heavy \\
\hline \multirow{4}{*}{ Hamirpur } & \multirow[t]{2}{*}{ Cauliflower } & Insects & 15 & 19 & 66 \\
\hline & & Diseases & 33 & 52 & 15 \\
\hline & \multirow[t]{2}{*}{ Brinjal } & Insects & 12 & 29 & 59 \\
\hline & & Diseases & 29 & 49 & 22 \\
\hline \multirow[t]{4}{*}{ Bilaspur } & \multirow[t]{2}{*}{ Cauliflower } & Insects & 14 & 25 & 61 \\
\hline & & Diseases & 54 & 27 & 19 \\
\hline & \multirow[t]{2}{*}{ Brinjal } & Insects & 14 & 26 & 60 \\
\hline & & Diseases & 46 & 37 & 17 \\
\hline \multirow[t]{4}{*}{ Una } & \multirow[t]{2}{*}{ Cauliflower } & Insects & 11 & 19 & 63 \\
\hline & & Diseases & 45 & 37 & 18 \\
\hline & \multirow[t]{2}{*}{ Brinjal } & Insects & 14 & 30 & 56 \\
\hline & & Diseases & 51 & 32 & 17 \\
\hline
\end{tabular}

Table.6 Pesticide storage, disposal and application practices adopted by farmers

\begin{tabular}{|c|c|c|c|c|}
\hline Particulars & Hamirpur & Bilaspur & Una & Average \\
\hline \multicolumn{5}{|l|}{ Pesticide storage after purchase } \\
\hline Safe storage & 82 & 78 & 84 & 81.33 \\
\hline Unsafe storage & 18 & 22 & 16 & 18.66 \\
\hline \multicolumn{5}{|l|}{ Disposal of pesticide containers } \\
\hline In field & 22 & 18 & 21 & 20.33 \\
\hline Sold/reuse & 59 & 66 & 60 & 61.66 \\
\hline Crushed/buried in soil & 19 & 16 & 19 & 18.00 \\
\hline \multicolumn{5}{|c|}{ Safety measures used by applicants } \\
\hline Use of face masks/ hand gloves & 37 & 35 & 36 & 36.00 \\
\hline Wash hands with soap & 80 & 79 & 81 & 80.00 \\
\hline \multicolumn{5}{|l|}{ Sprayer use practices } \\
\hline Use after wash & 77 & 71 & 74 & 74.00 \\
\hline Wash rarely or never wash & 23 & 29 & 26 & 26.00 \\
\hline
\end{tabular}

Majority of the farmers generally tend to use combination of one or more pesticides on the basis of their effectiveness and cost.

It was observed that vegetable cultivating farmers in the study area were aware of various issues related to pest management. On an average 62.33 per cent of the farmers were aware about pesticide hazards in vegetable cultivation. About 67.00 per cent farmer in
Hamirpur, 63.00 per cent in Bilaspur and 57.00 per cent of the farmers in Una knew about hazards of pesticide use. The knowledge about crop pests and IPM practices was also examined. Almost 36.33 per cent of sampled respondents were aware of IPM practices indicating their willingness to move towards safer pest control measures, which is a good sign for environmental friendly farming. About 52.33 per cent 
farmers knew about the pests of crops in vegetable cultivation (Table 3 ).

Farmers were accessing pest management information in many ways. Farmers obtained the information on pesticide use from multiple sources (Table 4). In the survey conducted, it was found that about 57.00 per cent of respondents were mainly dependent on the advice of pesticide dealers, followed by relatives/friends (23.66 per cent) as well as information from public extension system/SAU personnel (19.33 per cent). The data presented in Table 4 reveal that no farmer followed CIBRC guidelines for pest management. The inter comparison of the three district shows that farmers of Hamirpur had better access to authentic information, such as SAU personnel/State department of agriculture (25.00 per cent) compared to Bilaspur (14.00) and Una (19.00 per cent), showing the innovativeness as well as higher educational level of farmers in that district (Table 4).

There were various insect pests and diseases associated with cauliflower and brinjal in the monitored area. The farmers' knowledge on severity of insects and diseases in the vegetables was examined on the basis of three criteria namely slight, medium and heavy infestation/infection (Table 5). The severity of insect pests and diseases varied according to the microenvironment of the crops in the region. In cauliflower $66.00,61.00$ and 63.00 per cent of the farmers were of the same opinion that there was heavy severity of insects (diamond back moth, aphid and cabbage butterfly) in Hamirpur, Bilaspur and Una districts. Only 15.00, 19.00 and 18.00 per cent farmers reported heavy attack of diseases like damping off and black rot of cauliflower in Hamirpur, Bilaspur and Una districts, respectively. Farmers also perceived that there existed severity of insects and diseases in brinjal. Fruit and shot borer was major insect cause major damage to brinjal crop other insects were bettles, jassids and aphids reported by respondents. In brinjal 59.00, 60.00 and 56.00 per cent farmers reported heavy attack of insects in Hamirpur, Bilaspur and Una respectively. Diseases like phomosis blight and fruit rot of brinjal were also reported by brinjal growing farmers in all three surveyed districts of Himachal Pradesh.

It was observed that most of the farmers stored the pesticide bottles ( 81.33 per cent) at safe places in their houses (Table 6). The remaining (18.66 per cent) placed the bottles in unsafe areas without any safety measures. For the farmers, disposal of empty bottles was not a safety concern. Majority of farmers (61.66 per cent) sold or reused the empty bottles of pesticides after washing them properly especially large size containers. Only few farmers (18.00 per cent) adopted safe disposal methods like crushing/burying the empty containers in the soil (Table 6). Only 20.33 per cent of sampled farmers disposed the empty bottles in the fields or outside their houses. It was also found that 36 per cent of the farmers used self-protection and rest of the applicants did not used any safety measures like face masks/hand gloves etc. Majority of the farmers (80.00 per cent) washed their hands with soap after pesticide. Majority of the farmers (74.00 per cent) washed the sprayers with water after every use and rest (26.00 per cent) did not washed sprayer after use.

It was observed that farmers had limited knowledge of pest management as well as the consequences of pesticide use in vegetable cultivation. The study revealed that most commonly used insecticides, fungicides and acaricides on cauliflower and brinjal were malathion, mancozeb and propargite, respectively. The most effective pesticides in their opinion were malathion, chlorpyriphos, cypermethrin, carbendazim and mancozeb. 
Crop protection measures were being adopted by the farmers on the advice of pesticide dealers rather than agricultural extension officers or farm scientists. They also used the pesticides not approved by the CIBRC. The results showed that farmers need to take more precautionary and safety measures to keep their health as well as environment in good state. Increasing farmers' awareness of pesticide hazards to the environment and promotion of alternative pest management strategies such as use of IPM is essential for reducing adverse effect of pesticides on environment.

\section{References}

Ajayia OOC. 2000. Pesticide Use Practices, Productivity and Farmers' Health: The Case of Cotton-Rice Systems in Côte d'Ivoire, West Africa. In "Pesticide Policy Project Publication Series, No. 3 , ed. by $\mathrm{H}$. Waibel and C. Henckes, Publication of the Institute of Horticultural Economics, Uni Druck Hannover

Anand M. 2015. Green growth and agriculture in Himachal Pradesh. The Energy and Resources Institute, New Delhi, India, 28p.

Anonymous. 2015. Handbook of Indian horticulture database. National Horticulture Board, Gurgaon

Beketov MA, Kefford BJ, Schafer RB, Liess M (2013) Pesticides reduce regional biodiversity of stream invertebrates. PNAS USA 110:11039-11043

Gagandeep Singh, Dubey JK and Patyal SK. 2016. A study on farmers' knowledge, perception and intensity of approved pesticide use practices/patterns in tomato and cabbage in Himachal Pradesh. International Journal of Farm Sciences 6(3): 77-83

Lupwayi NZ, Harker KN, Dosdall LM, Turkington TK, Blackshaw RE, O’Donovan JT, Carcamo HA, Otani JK, Clayton GW 2009. Changes in functional structure of soil bacterial communities due to fungicide and insecticide applications in canola. Agriculture, Ecosystems and Environment 130: 109-114

Nyakundi WO, Magoma G, Ochora J, Nyende AB. 2010. A survey of pesticide use and application patterns among farmers: a case study from selected horticultural farms in rift valley and central provinces, Kenya. Proceedings JKUAT scientific technological and industrialization conference pp 618-630

Oerke EC. 2005. Centenary Review Crop Losses to Pests. Journal of Agricultural Science, 144: 31-43

Ongley ED (1996) Control of water pollution from agriculture - FAO irrigation and drainage paper 55. FAO, Rome

Wassemann MD. 1972. Effects of Organochorine insecticides on homeostatic and immunologic process, fate of pesticides in the environment, Gordon and Breach London.

Zacharia JT. 2011. Ecological Effects of Pesticides. In: Stoytcheva M (ed) Pesticides in the modern world - Risks and Benefits, Intech Publisher. pp 129142

\section{How to cite this article:}

Gaganpreet Singh Brar, Surender Kumar Patyal, Jatiender Kumar Dubey and Gagandeep Singh. 2018. Survey on Pesticide Use Pattern and Farmers Perceptions in Cauliflower and Brinjal Growing Areas in Three Districts of Himachal Pradesh, India. Int.J.Curr.Microbiol.App.Sci. 7(03): 2417-2423. doi: https://doi.org/10.20546/ijcmas.2018.703.281 